\title{
The New Syllabi for Cameroon Secondary Education: A Description of the Organisation of Salient Elements
}

\author{
Fedelis Lekeaka Alemnge \\ Department of Curriculum Studies and Teaching, Faculty of Education, University of Buea, Buea, Cameroon \\ Email: alemnge.fidelis@ubuea.cm
}

How to cite this paper: Alemnge, F.L. (2021) The New Syllabi for Cameroon Secondary Education: A Description of the Organisation of Salient Elements. Open Access Library Journal, 8: e6994. https://doi.org/10.4236/oalib.1106994

Received: November 14, 2020

Accepted: March 28, 2021

Published: March 31, 2021

Copyright $\odot 2021$ by author(s) and Open Access Library Inc.

This work is licensed under the Creative Commons Attribution International License (CC BY 4.0).

http://creativecommons.org/licenses/by/4.0/ (c) (i) Open Access

\begin{abstract}
This study sets out to describe the new secondary school syllabi that came into use in Cameroon in the 2014/2015 academic year superseding the syllabuses that had been in use in the past thirty years. The present syllabi have been created to reflect the national and international learning needs in terms of knowledge, know-how and attitudes. Cast in the Competency-Based Approach to teaching and learning, it draws from the vision of education contained in the Education for All goals (EFA), Jomtien (1990) [1], the Dakar (2000) [2] framework for action, Sustainable Development Goal, 4 to "Ensure inclusive and equitable quality education and promote lifelong learning opportunities for all" (p. 18, 2015) [3], the national education policy and the Growth and Employment Strategy Paper (GESP, 2010) [4] which carries Cameroon Vision 2035. Structured into five "area of learning", with different weights, the syllabi are held together by "Families of situations" around which teaching and learning activities are developed and implemented in a bid to enable learners develop both the subject competences, as well as, the cross-curricula competences. The specific roles of learners', teachers', parents', and the community are clearly delineated to facilitate implementation.
\end{abstract}

\section{Subject Areas}

Education

\section{Keywords}

Syllabi, Syllabus, Competence-Based Approach, Areas of Learning, Families of Situations, Modules, Real-life Situations, Learner-Centred, Competences, Cross-Curricula Competences 


\section{Introduction}

At independence, Cameroon inherited two educational systems; a Francophone subsystem in the mandated East Cameroon in 1960 and an Anglo-Saxon sub system; in the mandated Anglophone West Cameroon in 1961. In the nation's search for the best course of action to take in order to resolve this very important issue of national and international interest, they opted for a reformed secondary school programme that will bring together the best in both subsystems while ensuring that the programme was anchored in the local realities of the Cameroon society. In pursuit of this goal and acting independently the governments of East Cameroon and West Cameroon passed a similar law in 1963 whose implementation should have resulted in a harmonized secondary school programme for the country (Alemnge, 2019) [5].

From the Federal Republic in 1961 through the United Republic of 1972, to the Republic in 1982 efforts have been ongoing in a bid to realize the set goal of harmonizing the secondary school programmes. Meanwhile the content of educational programmes and teaching materials continued to deteriorate nationwide leading to a general outcry from all education stake holders for the system to be adequately reformed. This led the government to organize a national Forum on Education in 1995 to which all stake holders were invited and charged with the responsibility to make proposals to government for the long-awaited reforms. The Forum met and made proposals to government addressing all aspects of the education. The recommendations proposed by the Forum were exploited and led to the publication of the National Education Policy, encapsulated in the Law of 1998 to Lay down guidelines for Education in Cameroon.

However, the long awaited reform leading to the new and harmonized secondary schools' syllabi found expression within the general reform movement (GESP, 2010 [4]) aimed at transforming the national economy from producing and commercializing primary products to an emergent one by 2035 that will add value to its products by transforming them into finished product before sale. Therefore, the new syllabi are guided by the desire to produce the human resources that will be imbued, with the required skills, knowledge, attitudes and creativity to be able to transform the society to achieve emergence by 2035 (GESP, $2010[4]$ ).

\subsection{Context of the Reform}

In line with universal educational requirements to provide for a school system that empowers learners to develop their latent potential to cope with increasing complexities of life, facilitate insertion into the job market and become autonomous learners, pursuing lifelong learning, the new syllabi are designed to reflect local knowledge culture and promote sustainable development by school leavers. To achieve the above and in line with the objectives of national educational policy (law no. 98/004 of 14 April 1998) [6] to lay down guidelines for education in Cameroon, the new pedagogic paradigm chosen is "the competency 
based approach with entry through real life situation" the new syllabi are in tandem with the provisions of the Growth and Employment Strategies Paper (GESP) (2010) [4] which specifies the minimum amount of knowledge, skills and attitudes each Cameroonian school child is expected to possess by the time they graduate from the first cycle of secondary education. Together with the accompanying Teachers Guides, the syllabi provide teachers an enabling framework to organize their pedagogic activities.

\subsection{Statement of the Problem}

Upon the defeat of Germany during the First World War, Cameroon (a German territory) was divided and given to France and Britain as the spoils of war. Each introduced its educational system in its own part of the territory. Having obtained independence, the two parts decided to come together as one nation but now had to resolve this major issue to enhance national unity and integration. The existence of the separate systems generated a number of issues among which were quality of educational offerings, equivalence of certificates, group versus individual subject certificates, and the strong prejudices by members of each sub system who held and projected theirs to be superior to the other. This kept Cameroonians divided in this very important aspect of national life. Anglophones remained alert in protecting an educational subsystem they held in very high esteem from the machinations of the government (which has always been dominated by Francophones) which made several attempts to subsume the subsystem into that of the Francophones. Consequently, the creation of a common secondary school programme taught in French in the francophone regions and in English in the Anglophone regions and examined in relation to the specificities of each subsystem's evaluation criteria is crucial to resolving one of the major national problems that Cameroon has been grappling with since independence.

\subsection{Study Design}

This study is carried out using the Documentary analysis design. In this light, documentary evidence will constitute the main source of research data. Data will be collected from the following primary source documents. The published New secondary school syllabi for first cycle of secondary education in Cameroon, The Teachers' guides for the syllabi, the Growth and Employment Strategy Paper, and the National Education Policy law.

An examination of the syllabi will enable the researcher identify and describe the general organization of the syllabi and the organization of the individual subjects of study. An analysis of the Teachers' guides will bring out the pedagogical orientations of the syllabi. The Growth and Employment strategy Paper and the motional education policy documents will contribute to an understanding of their influence in the preparation of the syllabuses. All these are deliberate sources which in the view of (Elton 1967 p. 101 [6][6] and Lehmann and Mehrens, 1971 p. 24) as cited in Bell (1993) [7] are documents deliberately pre- 
served as evidence for the future to serve for purposes of self-justification or reputation enhancement. These are public records written for specific purposes but all interrelated as they share a common goal, which is the transformation of the Cameroon society from an agricultural to a semi-industrial one by 2035 . The documents are, therefore, valid and reliable as they fulfil the conditions of authenticity, credibility, representativeness and meaning suggested by Scott (1990) [8].

\section{Literature Review}

Luke, Woods, and Weir (2012) [9] perceive a syllabus as a map and a descriptive overview of the curriculum, a structured summary or outline of what should be taught and learned across the schooling years. It is an outline of the preferred expected knowledge, skills, competences, performances, with affiliated specifications of expected standards. In this connection, Michael (2005) [10] argues that:

Liberal arts education proposes that our lives are shaped both by the individual choices we make and the broader historical and structural forces we have relatively little control over. In the same vein, there are forces operating within classrooms that shape educational outcomes. What students accomplish over the course of a term irrespective of the subject area, is a product of the combination of student's individual efforts and abilities, teachers and the structure of the subject itself. Therefore, the form and content of a subject syllabus is of consequence in the teaching of all disciplines.

In essence, there are four general principles of syllabus construction. These include aims and objectives, content and sequencing, assessment and evaluation and administration and presentation. However, the paradigm shift from a focus on teaching to that on learning has triggered new ways of organizing syllabuses which are learner-centered to meet the needs of the shift in pedagogy.

\subsection{Aims and Objectives}

Educational aims and objectives are the foundational elements on which the syllabus outline is constructed. While aims are broad statements identifying the general educational outcomes, the state wants students to display upon graduation from secondary school, objectives are the concrete measures through which the goals will be realized and are usually expressed as relationships between specific concepts. In preparing learner-centered syllabuses however, Diamond (1998) [11] argues for a clear statement of learning goals and student learning outcomes in the syllabus. He argues that such goals and outcomes should foster the creation of learner-centered environments and an atmosphere that will facilitate the development of positive personal and interpersonal relationships, higher-order thinking, creativity, take care of students' ideas and opinions, address their individual needs and beliefs and promote self-regulatory learning as part of the syllabus expectations and goals. In this connection, Halpern and Ha- 
kel (2003) [12] conclude that the main reasons for education are the transfer of learning, using what one has learned to solve problems in other contexts.

The aim and objectives of primary and secondary education in Cameroon are articulated in the policy law no. 98/004 of 14 April 1998 [6], to lay down guidelines for education in Cameroon. The secondary school syllabi have been created using the aims and objectives contained therein and in related policy documents such as the Growth and Employment Strategy paper (2009) [4], Socle Nationale de Competence (2013) [13] and Vision 2035 (2009) [14].

\subsection{Objectives and Learning Styles}

In preparing a subject syllabus, it is essential to remember that we all learn at least through three of our fine senses with one being dominant. Learning takes place through hearing (audio) seeing (visual) and doing (kinesthetic) which may also involve taste and smell. This Audio, Visual and Kinesthetic (AVK) model of learning enables us to understand that we learn differently and therefore the syllabus needs to incorporate this into its fabric in order to help maximize the learning potential of each student.

Concomitantly, Diamond (1998) [11] posits that it is of great importance to communicate high standards for students which must be clearly articulated in the learner-centered syllabus. In this connection, the following objectives of a learner-centered syllabus are proposed:

1) Define the student's responsibilities.

2) Define the instructor's role and responsibilities.

3) Provide goals and student learning outcomes.

4) Establish standards and procedures for evaluation.

Students need to be aware of the role they will assume in the subject. Consequently, the purpose of defining student responsibilities is to assist them take control of their learning and to promote lifelong learning. This also requires that learning spaces be organized to focus on individual learning and that pedagogical strategies promote knowledge on how students learn.

The learner-centered syllabus should define clearly the role of the teacher because this paradigm positions the teacher differently from the traditional classroom paradigm and consequently, students and teachers need to know and understand that this classroom will function differently and this can be communicated in the subject syllabus. This becomes very important in a school system as that in Cameroon where some of the teachers have received rigorous training only in their academic disciplines without the essential and complementary pedagogic training in educational learning theories. In this light, Robertson (1999) [15] proposes a teacher development model in which such teachers move from a mastery of the content (egocentrism) through considering various teaching strategies to engage learners (aliocentrism) to when he or she critically reflects on practice ad acknowledges it as part of the growth process (systemocentrism). 


\subsection{Preparing the Content of the Syllabus}

All decisions made concerning content relate to the materials, the sequencing and the mode of instruction that will facilitate students' efforts to achieve the objectives. In making decisions about the content, the author(s) will usually organize it in one form or another (chapters, modules or topics). Generally, sequencing content from simple to increasingly complex material is used but a different strategy will have to be used if content with roughly equal difficulty has to be covered. At the same time, sequencing ensures that the relationships between subjects and between subjects covered by the syllabus are articulated to bring out the holistic nature of the syllabus. The decision-making process here is brought to a close by the determination of the reading materials and textbooks for the subjects of the syllabi. As a general rule, the syllabus contents should be so clear that they are easily understood by learners (Habanek, 2005) [16] The syllabus should provide enough detail for students to understand what is expected of them and how the course proceeds (Diamond, 1998) [11]. In addition, the course syllabus should generate interest and motivate students to take responsibility to learn the contents of the course (Grunet, 1997) [17].

\subsection{Defining Evaluation Strategies}

Students are aware that the grades one receives in class have a positive or negative effect on their overall performance especially in systems like the one in Cameroon where test scores have a high stake on the overall performance. The learner-centered syllabus is expected to not only evaluate procedures but also grading scales and student performance monitoring instruments. Consequently, the inclusion of all levels of the Bloom's (1956) taxonomy (Knowledge, Comprehension, Application, Analysis, Synthesis and Evaluation) of educational objectives is highly encouraged by educational learning theorists in the evaluation of instruction in learner-centered classrooms (Peter K, Martin M, 2005) [18]. Given this perspective therefore, making provisions for students to exercise their preferences in the types of assessments to take can motivate them to increase performance since choices will be based on students' interests and promote autonomy. Consequently, activities such as group work, projects, self-evaluation, portfolios, learning contracts, and presentations can serve as preferable and more valuable options to traditional evaluation strategies.

Social constructivism, in contrast to the individual constructivists, is based on the assumption that learning is collaborative with meaning negotiated from a multiplicity of perspectives. Vygotsky (1980) [19] felt social learning precedes development. As with individual constructivism, there is no general agreement on how this knowledge is in practice negotiated.

"Contextualism is buttressed by the assumptions that learning should occur in real life settings, and testing should be integrated into the learning tasks. Educators generally refer to learning related to a context as 'situated cognition' 
(Brown, Collins, and Duguid, 1989; Henning, 2004) [20]. Proponents of contextualism recommend that learning problems be presented to learners in situations akin to real life and common to everyday application. This type of learning is described as 'authentic learning' and the instruction related to the learning situation as 'anchord' in real life situations (Cognition and Technology Group, 1990; Streibel, 1989) [21]".

\section{Overview of the Secondary School Syllabi}

The syllabi of the first cycle of Secondary General Education are divided into two levels (Level 1: Forms 1 and 2; Level 2 Forms 3, 4 and 5) and organised into 5 Areas of Learning. Each area of learning contains a number of related disciplines. This is accompanied by the prescribed weekly workload per area of learning and the expected learning outcomes of each area of learning at the end of the level. Learners are required to acquire knowledge, competences and attitudes in each subject and area of learning, but they are also expected to acquire other accompanying skills described as cross-curricula competences related to intellectual, methodological, social and personal areas of learning. Table 1 is a summary general presentation of the Areas of Learning, their related disciplines, learning load per week, the expected terminal learning outcomes and the cross-curricula competences.

\section{Teaching and Learning}

The preparation and presentation of instruction are to be carried out within the defined framework of prescribed Domains or Areas of Life and their accompanying prescribed Families of situations. Teachers have been given the latitude to contribute to the framework by identifying and using other families of situations relevant to their local environments in the preparation and delivery of instruction but are constraint to use the prescribed situations if they are not creative enough to identify relevant local situations. The resources to be mobilised by the learner in relation to their development of the subject and cross-curricula competences, are found in many disciplines and areas of learning. Consequently, teachers are called upon to implement these syllabi not in isolation but as interrelated subjects through teaching/learning activities of the different subjects. The effective implementation of the syllabi ultimately depends on the participation and collaboration of all the education stake holders as they are capable of inspiring an educative project and putting in place extracurricular activities. "The ultimate training goal of these syllabi, at the end of the first cycle, is to enable the learner to be self-reliant, to be able to keep on learning throughout his/her life, to contribute to sustainable development and become a responsible citizen". Table 2 shows the prescribed areas of life and families of situations for the first cycle of general secondary education while Table 3 presents the general syllabi presentation matrix. 
Table 1. General overview of the syllabus.

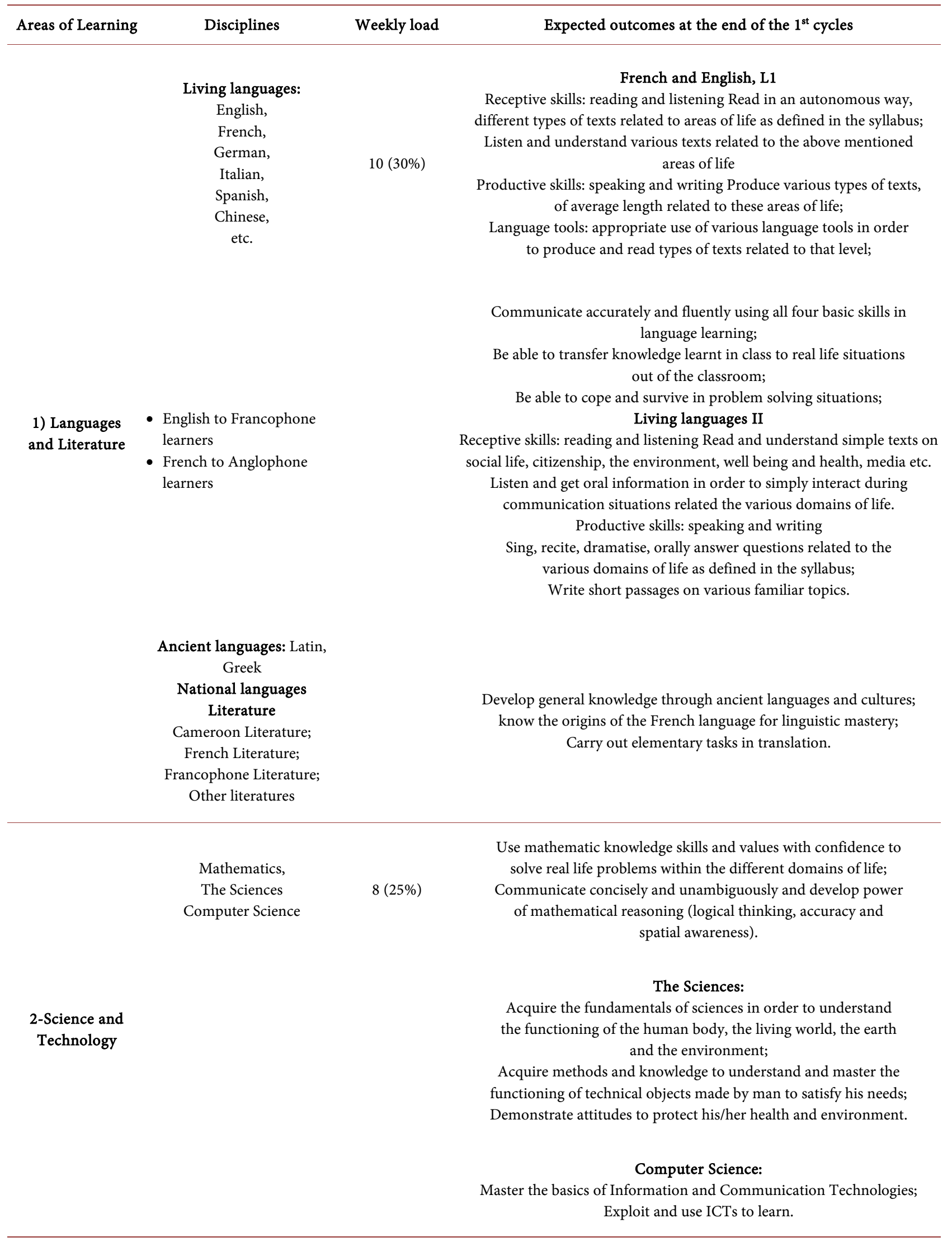


History

\section{3) Social Sciences/ Humanities}

Geography

$6(20 \%)$

Citizenship Education

4) Personal

Development

Sports and Physical

Education

Health Education
Possess cultural references to better locate events in time and space within a democratic system and become a responsible citizen.

\section{History:}

Acquire a common culture; be aware of heritage from the past and current challenges;

\section{Geography:}

Develop one's curiosity and knowledge of the world; Get acquainted with landmarks to find your way and fit in the world.

\section{Citizenship Education:}

Possess essential knowledge in rights and duties in order to fulfil his/her citizenship.
5) Arts and National Cultures
Arts/Artistic Education;

National Cultures
Develop his/her physical abilities/skills;

Get ready for physical challenges, save and regain energy after physical efforts;

Identify risk factors; possess basic knowledge and principles in hygiene and health education;

Demonstrate a sense of self control and appreciate the effect of physical activities.

Conceive and draw up sports and cultural animation projects; Acquire methods and develop a high sense of efforts; Conceive, draw up and implement projects that will enable one

to project his/her image and feel the well being inspired by self-confidence.

\section{Artistic Education:}

Observe and appreciate works of art ;

Carry out an artistic activity;

Gradually acquire the love for personal expression and creativity;

Possess a mastery of creativity in music, plastic arts and the performing arts.

Dramatise, recite texts (poems, tales, proverbs, etc.) relating to various areas of society;

Practise the different dramatic genres: sketches, comedy, tragedy, drama, etc.

\section{National languages and Cultures:}

Demonstrate a mastery of Cameroon cultures;

Visit the various cultural areas of the country in order to discover their characteristics;

Demonstrate a mastery of basic rules in writing Cameroonian

languages as well as basic grammatical notions applied to these languages;

Demonstrate a mastery of one of the national languages at 3 levels: morpho-syntax, reception and production of simple oral and written texts. 


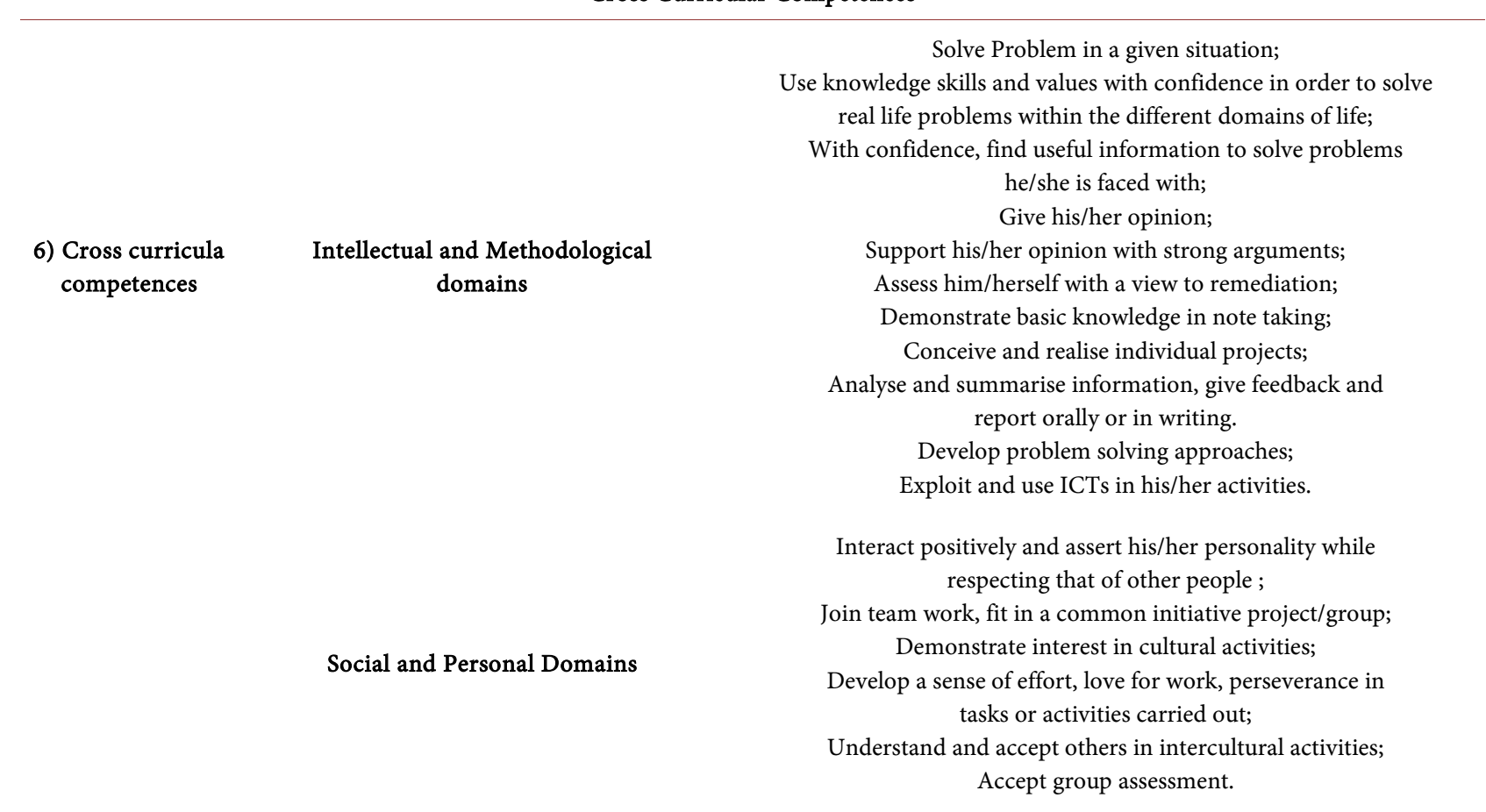

Table 2. Domains of life and families of situations.

\begin{tabular}{|c|c|c|}
\hline $\mathrm{N}^{\circ}$ & Domains/Areas of life & Families of Situations to be Treated in the $1^{\text {st }}$ Cycle \\
\hline 1 & Family and Social life & $\begin{array}{l}\text { Participation in family life } \\
\text { Healthy professional relationships } \\
\text { Social integration }\end{array}$ \\
\hline 2 & Economic Life & $\begin{array}{l}\text { Discovery of income generating activities } \\
\text { Discovery of the job market, social roles, jobs and professions } \\
\text { Self-confidence, aspirations, talents, self-potential } \\
\text { Practising healthy eating habits }\end{array}$ \\
\hline 3 & Environment, Health and Well Being & $\begin{array}{l}\text { Preservation of the Environment } \\
\text { Quest for a healthy life style } \\
\text { Choosing and practising a healthy life style }\end{array}$ \\
\hline 4 & Citizenship & $\begin{array}{l}\text { Mastery of rules and regulations governing the Cameroonian society } \\
\text { Discovery of cultural values and customs of the Cameroonian society }\end{array}$ \\
\hline 5 & Media and Communications & $\begin{array}{l}\text { Discovery of the media world } \\
\text { Discovery of Information and Communication Technologies }\end{array}$ \\
\hline
\end{tabular}

Source: Programme of study: Literature in English (Anglophone) Forms 1 and 2 p. 7 [22].

Table 3. General syllabus presentation matrix.

\begin{tabular}{|c|c|c|c|c|c|c|c|}
\hline \multicolumn{2}{|c|}{ Contextual Framework } & \multicolumn{2}{|c|}{ Competences } & \multicolumn{4}{|c|}{ Resources } \\
\hline $\begin{array}{l}\text { Families of } \\
\text { Situations }\end{array}$ & $\begin{array}{l}\text { Examples of } \\
\text { Real-Life } \\
\text { situations }\end{array}$ & $\begin{array}{c}\text { Categories of } \\
\text { Actions }\end{array}$ & $\begin{array}{l}\text { Examples } \\
\text { of Actions }\end{array}$ & $\begin{array}{c}\text { Content (Core } \\
\text { Knowledge) }\end{array}$ & $\begin{array}{l}\text { Aptitude } \\
\text { (Skills) }\end{array}$ & Attitudes & $\begin{array}{c}\text { Other } \\
\text { Resources }\end{array}$ \\
\hline
\end{tabular}

Source: Biology Syllabus Forms 1 and Form 2 p. 18 [23]. 


\section{Syllabus Outline by Subject}

The contents of the syllabi are arranged in the following order; general introduction to the subject, profile of the learner, competences, families of situations, reading and understanding, assessment and the services of the modules.

\subsection{The General Subject Introduction}

The subject introduction highlights the role of the subject area in national development, and explains the contribution of the subject in conjunction with others in the life of the learner. It also states the contribution, the subject is expected to make within the learning area to the further development of knowledge, knowhow and attitudes of the learner from the precedent stage of learning. It provides the purpose of the programme and the rationale for the subject in the curriculum.

\subsection{The Learner Profiles}

The profile lists the expected learning outcomes in terms of the number of practical activities that the learner should demonstrate in various real-life situations. It explains why the design and teaching of the syllabus are centered on the competency Based Approach (CBA) and states that teaching should begin with the identification of a real life problem or situation which will find a solution, through the scientific process of defining the competencies needed to transform, modify or improve the situation, to the identification and mobilization of the appropriate resources needed to act upon it. This will challenge learners to use scientific methods to actively engage in the construction of their own knowledge, develop the knowhow and attitudes to seek solutions to real life problems in different settings. In the context of these syllabi therefore, competences are objectives since they link school knowledge to real live situations in the community or environments where the learner lives. The knowledge, knowhow and attitudes acquired by the learner are consequently, a means to an end and not ends to themselves.

\subsection{Competences}

The various competences that the learner is expected to develop by the end of the particular level in the subject area are outlined in relation to how the content knowledge of the subject is organised.

\subsection{Families of Situations}

The syllabus for each subject presents a family of situations through which teachers will concretize the teaching and learning of the content of each module. These prescribed groups of situations are not exhaustive but provide a frame of reference to help teachers in adding other situations to the groups during the implementation of the syllabus as the context requires.

\subsection{Reading and Understanding the Syllabus}

The teacher's attention is drawn to the way the syllabus is presented, since this 
understanding is important in guiding the implementers on how the lessons will be prepared and presented. It is crucial because it marks a departure from the way lessons were prepared and presented in the former syllabuses. The syllabi are presented in a tabula matrix of three major columns each having its own sub columns. The main columns are termed, "contextual framework", "competencies" and "resources". The contextual framework is divided into two columns; one column carrying the group of situations through which content is to be taught while the other contains the corresponding examples of real-life situations where learning can be applied.

Teachers are expected to draw inspiration from these examples in identifying and defining others relevant to the local context. The competencies are made up of two columns; categories of actions and examples of actions. The suggested groups of actions are related to learner's mastery of the competences expected to be developed through the study of the module and are supposed to be added unto by teachers in relation to the needs of their local situations.

The third column "resources" consists of four sub columns: context, aptitude, attitudes and other resources. This provides the core knowledge which provides the set of cognitive, affective and psychomotor resources needed by the learners to successfully treat a family of situation. Other resources are the teaching and learning media, financial and human resources needed for successful teaching and learning (see Table 4 below).

\subsection{Assessment}

This section begins with a statement of the goal of the syllabus, followed by a listing of the knowledge, competences, (skills, abilities) and attitudes that will be tested, including specific guidelines where necessary about how to proceed with a test depending on its nature.

\section{Modules}

\subsection{Overview}

The syllabus for each class (Forms 1 to 5 ) is organized into 3 to 5 modules depending on the nature of the content to be covered. Each module is sub divided into topics which are in turn divided into chapters and then into daily lessons, though some chapters constitute a daily lesson. This section presents the level, class, module titles, families of situations and the stipulated number of hours that will be used in completing the syllabus. This allocated time is then subdivided into the number of lesson periods that make up the module covered by the syllabus, as can be seen in Table 5 and Table 6.

\subsubsection{Brief Presentation of the Modules}

The individual modules of the subject syllabus highlight the main concepts to be taught, the competences that it will enable learners develop, the contribution it brings to outcomes and goals of the curriculum, contribution to the learning area and how it is going to contribute to all the other areas of living in the society. 
Table 4. Lesson format (form 1 biology).

\begin{tabular}{|c|c|c|c|c|c|c|c|}
\hline \multicolumn{2}{|c|}{ Contextual Framework } & \multicolumn{2}{|c|}{ Competences } & \multicolumn{4}{|c|}{ Resources } \\
\hline $\begin{array}{l}\text { Families of } \\
\text { Situations }\end{array}$ & $\begin{array}{l}\text { Examples } \\
\text { of Real-Life } \\
\text { Situations }\end{array}$ & $\begin{array}{c}\text { Categories of } \\
\text { Actions }\end{array}$ & $\begin{array}{l}\text { Examples of } \\
\text { Actions }\end{array}$ & $\begin{array}{l}\text { Content Core } \\
\text { Knowledge }\end{array}$ & Aptitude (Skills) & Attitudes & $\begin{array}{c}\text { Other } \\
\text { Resources }\end{array}$ \\
\hline $\begin{array}{l}\text { Supply of } \\
\text { Man's Needs } \\
\text { in Animal } \\
\text { and Plant } \\
\text { Resources }\end{array}$ & $\begin{array}{l}\text { Understanding } \\
\text { Life and Life } \\
\text { Forms }\end{array}$ & $\begin{array}{l}\text { Appropriating } \\
\text { Knowledge } \\
\text { of Life and } \\
\text { Life Forms }\end{array}$ & $\begin{array}{l}\text { - distinguishing } \\
\text { between living } \\
\text { and non living } \\
\text { things; } \\
\text { - describing and } \\
\text { explaining the } \\
\text { scientific way } \\
\text { of acquiring } \\
\text { knowledge } \\
\text { and solving } \\
\text { problems; } \\
\text { - Creating } \\
\text { observation } \\
\text { charts and } \\
\text { nature's } \\
\text { calendars; } \\
\text { - constructing } \\
\text { simple vivaria; } \\
\text { - communicating } \\
\text { scientific } \\
\text { information; } \\
\text { - describing the } \\
\text { differences } \\
\text { between plant } \\
\text { and animal cells; } \\
\text { - distinguishing } \\
\text { different types } \\
\text { of cells as the } \\
\text { origin and } \\
\text { building } \\
\text { blocks of life. }\end{array}$ & $\begin{array}{l}\text { Introduction to } \\
\text { biology } \\
\text { 1) Definition and } \\
\text { branches } \\
\text { 2) Relationship with } \\
\text { other science subjects } \\
\text { 3) Relevance to daily } \\
\text { life } \\
\text { 4) Characteristics } \\
\text { of living things and } \\
\text { differences between } \\
\text { living and non-living } \\
\text { things } \\
\text { 5) Differences } \\
\text { between plants and } \\
\text { animals } \\
\text { 6) Studying living } \\
\text { things } \\
\text { a) The scientific } \\
\text { approach } \\
\text { b) Observing living } \\
\text { organisms (in their } \\
\text { habitats and in the } \\
\text { laboratory) } \\
\text { i) Equipment/tools } \\
\text { for observation (lens, } \\
\text { microscope, the five } \\
\text { senses, etc.) } \\
\text { ii) Describing and } \\
\text { plant and animal cells; } \\
\text { reproductive and growth } \\
\text { cells; bacterial and } \\
\text { protoctist cells. } \\
\text { in biology observations } \\
\text { c) The cell as the } \\
\text { basic structural and } \\
\text { functional unit of life. } \\
\text { This should be strictly } \\
\text { limited to the cell as } \\
\text { seen with the light } \\
\text { microscope (cell } \\
\text { membrane, cytoplasm } \\
\text { and nucleus only). } \\
\end{array}$ & $\begin{array}{l}\text { - define biology } \\
\text { and branches; } \\
\text { - explain the } \\
\text { relationship } \\
\text { between biology } \\
\text { and the other } \\
\text { sciences; } \\
\text { - describe and } \\
\text { distinguish } \\
\text { between biology• } \\
\text { related careers; } \\
\text { - the role of } \\
\text { biological } \\
\text { knowledge in } \\
\text { solving daily } \\
\text { life problems; } \\
\text { - differentiate } \\
\text { between living } \\
\text { and non-living } \\
\text { things } \\
\text { (animal/plant } \\
\text { versus motor } \\
\text { car/robots... } \\
\text { etc.); } \\
\text { - } \\
\text { animal cells; } \\
\text { cell as the origin } \\
\text { and building } \\
\text { blocks of life. } \\
\text { investigate } \\
\text { nature and/or } \\
\text { solve problems; } \\
\text { - protect nature, } \\
\text { life and life } \\
\text { forms; } \\
\text { - observe, } \\
\text { describe and } \\
\text { appreciate the } \\
\text { beauty of } \\
\text { organisms in } \\
\text { their natural } \\
\text { milieu; } \\
\text { - }\end{array}$ & $\begin{array}{l}\text { Curiosity } \\
\text { and sense of } \\
\text { observation } \\
\text { - Respect of others } \\
\text { opinions } \\
\text { - Interest in } \\
\text { scientific } \\
\text { advancement } \\
\text { Open-mindedness } \\
\text { - Patience-Love for } \\
\text { nature } \\
\text { - Team spirit and } \\
\text { cooperation } \\
\text { - Decision making } \\
\text { and critical spirit } \\
\text { - Creative thinking } \\
\text { - Logical reasoning } \\
\text { - Methodological } \\
\text { action } \\
\text { - Problem solving } \\
\text { - Management and } \\
\text { respect for the } \\
\text { environment } \\
\text { - Effective } \\
\text { communication } \\
\end{array}$ & $\begin{array}{l}\text { - Didactic } \\
\text { materials- } \\
\text { charts, } \\
\text { models, } \\
\text { microscope, } \\
\text { etc.; biology } \\
\text { related } \\
\text { fields, } \\
\text { institutions, } \\
\text { companies, } \\
\text { Professional } \\
\end{array}$ \\
\hline
\end{tabular}

Source: Biology Syllabus for Forms 1 \& 2, Pages 26-27 [23]. 
Table 5. Biology syllabus, forms $1 \& 2$.

\begin{tabular}{ccc}
\hline Class & Module Title & $\begin{array}{c}\text { Relative Duration Per Module/Hours } \\
\text { And/Or Periods }\end{array}$ \\
\hline Form 1 & 1 & 20 (24 Periods \\
& 2 & 15 (18 periods) \\
& 3 & 15 (18 periods) \\
\hline Form 2 & 1 & 15 (18 periods) \\
& 2 & 20 (24periods) \\
& 3 & 15 (18 periods) \\
\hline
\end{tabular}

Source: Biology syllabus, form 1 \& 2, p 19 [23].

Table 6. Mathematics teaching syllabus for forms 3, 4 \& 5 .

\begin{tabular}{|c|c|c|c|}
\hline Level & Title of Module & Family of Situations & Duration \\
\hline \multirow{5}{*}{ Form 3} & $\begin{array}{l}\text { Numbers, Fundamental } \\
\text { Operations and Relationships } \\
\text { in the Sets of Numbers and } \\
\text { Between Elements in a Set }\end{array}$ & $\begin{array}{l}\text { Representation, determination } \\
\text { of quantities and identification } \\
\text { of objects by numbers }\end{array}$ & 20 \\
\hline & Plane Geometry & $\begin{array}{l}\text { Representations and transformations of } \\
\text { points and plane shapes within } \\
\text { the environment }\end{array}$ & 24 \\
\hline & Solid Figures & Usage of technical objects in everyday life & 10 \\
\hline & Statistics and Probability & $\begin{array}{l}\text { Organization of information, estimation } \\
\text { of quantities and making choices in the } \\
\text { consumption of goods and services }\end{array}$ & 10 \\
\hline & Algebra and Logic & $\begin{array}{l}\text { Description of patterns and relationships } \\
\text { between quantities and ideas using symbols }\end{array}$ & 40 \\
\hline \multirow{3}{*}{ Form 4} & $\begin{array}{l}\text { Numbers, Fundamental } \\
\text { Operations and Relationships } \\
\text { in the Sets of Numbers and } \\
\text { Between Elements in a Set }\end{array}$ & $\begin{array}{l}\text { Representation, determination of } \\
\text { quantities and identification of } \\
\text { objects by numbers }\end{array}$ & 24 \\
\hline & Plane Geometry & $\begin{array}{l}\text { Representations and transformations } \\
\text { of points and plane shapes within } \\
\text { the environment }\end{array}$ & 44 \\
\hline & Algebra and Logic & $\begin{array}{l}\text { Description of patterns and relationships } \\
\text { between quantities and ideas using symbols }\end{array}$ & 36 \\
\hline \multirow{3}{*}{ Form 5} & Plane Geometry & $\begin{array}{l}\text { Representations and transformations } \\
\text { of points and plane shapes within } \\
\text { the environment }\end{array}$ & 44 \\
\hline & Solid Figures & Usage of technical objects in everyday life & 20 \\
\hline & Statistics and Probability & $\begin{array}{l}\text { Organization of information, estimation } \\
\text { of quantities and making choices in the } \\
\text { consumption of goods and services }\end{array}$ & 40 \\
\hline
\end{tabular}

Source: Mathematics teaching syllabus for forms 3, 4 \& 5 pp. 18-19 [24]. 


\subsubsection{Interpretations and Use of the Syllabus Grid}

Regarding interpretations, teachers are informed about the elements which constitute the horizontal and vertical axis of the syllabus grid and reminded of the necessity to give pride of place during the preparation and delivery of instruction to the situations and actions in his/her immediate environment but is not allowed to change or modify the prescribed families of situations. In the conception of the syllabi, each subject is divided into modules, and each module corresponds to a topic which is divided into chapters and then into lessons, though some chapters form a single lesson.

Further study, practical work and guided work accompany some lessons and are obligatory. Where these occur, they are allocated a duration. These practical and guided works are complete lessons and must follow the same procedure for lesson preparation by teachers. Furthermore, the rubric "other resources" refers to external resources, that is, instructional material and human resources that are needed for the successful implementation of the lesson.

In relation to how the syllabus grid should be used, teachers are advised to first consult the "conceptual framework" and "competent functioning" columns. From these columns the teacher should identify the group of situations and categories of actions relevant to her/his immediate environment to use in preparing the lesson, failing to do so; she/he should use the situations and actions listed in the grid to prepare the lesson. In preparing the lessons, the teacher should ensure that the teaching and learning activities are always in line with the families of situations and the categories of activities prescribed.

\subsubsection{Methodological Approach}

The teaching methodology prescribed is the competency-based approach (CBA) to learning which is learner centered and consequently, only active teaching methods and techniques which place the learner at the center of instruction should be used. The teacher' guides presents several samples of relevant learner centred teaching methods and techniques. The presentation of each method is followed by a detailed explanation on how it can be used in the teaching and learning interaction.

\subsubsection{Teacher' Guides}

The teacher pedagogic guides include among others: a general introduction, the relationship between the specific subject syllabus and other components of the curriculum, the competences learners will develop, orientations for teaching and learning, lesson preparation procedures and some sample lessons. A glossary of the terms used is provided.

\subsubsection{Relationship between the Syllabus and Curriculum Components}

The teacher guide presents the relationship of the specific subjects within the specific learning area (e.g. science and technology) with the other learning areas. The contents of what will be taught for that level (class $1 \& 2$ or class $3,4 \& 5$ ) are grouped into some families of situations within the prescribed domains of 
life through which learners will be exposed to experience all the possible daily activities. Following this is an explanation of how the subjects within the area of learning are presented. Finally, the relationship between the syllabus and all the other subjects of the curriculum is presented.

These relationships are expected to help the teacher to understand that the subject is not standing on its own and therefore, cannot be taught in isolation. It enables teachers understand the links between the subject he/she is teaching with the subject's other colleagues are teaching in other areas of the curriculum. Consequently, they are expected to share this holistic vision of teaching and learning the curriculum with learners who are required to integrate all they are learning to develop their capacities to solve daily problems in all aspects of life. This calls for a paradigm shift from teachers and learners as the implementation of the former syllabus was teacher-centred and the learners' passive recipients of knowledge.

The competences that the syllabus is expected to assist learners to acquire are presented. The presentation of the subject competences is followed by a presentation of the cross curricula competences that the teaching and learning from other subjects will help learners to develop and use in their daily pursuit of resolving issues and problems confronting them, thus enhancing their creativity and autonomy.

\subsubsection{The Role of the Teacher}

Within the ambit of the prescribed methodology, (learner-centred and integrative pedagogy) the teacher's new role as a facilitator and supervisor of learning is highlighted and explained. A detailed list of his/her responsibilities is provided with explanations on how he/she should approach each responsibility.

\subsubsection{The Role of the Learner}

To be successful the learner is required to allocate enough time for her/his studies, exert and sustain enough effort in learning and that success will create additional motivation for further learning. As the learner persists in learning, she/he must seize all the opportunities thrust in her/his way both within and outside the classroom to deepen her/his knowledge, competences, and attitudes of the surrounding environment and of its scientific and technological culture.

\subsubsection{The Role of Parents}

Parents are assigned the responsibilities of supporting the teachers and working in collaboration with school authorities to foster the education of their children by accompanying the children with their studies at home, making the home a comfortable and enabling learning environment, and making the home a vehicle for acculturation and socialisation.

\subsubsection{The Role of the Community}

In the context of the syllabuses the community refers to all education stakeholders who include: "government, local administrative authorities, school manage- 
ment boards, Parent-Teacher Associations (PTA) and private educational providers". The role of the community is defined in terms of its obligations towards learners, teachers, school administrators and learning spaces. Consequently, it calls for their provision of adequate learning environments that inspire learners to have big dreams, provide apprenticeship, and opportunities for transfer of knowledge, encourage exchange of information and foster collaboration and cooperation between teachers and curriculum workers among others.

\subsubsection{Reading and Interpreting the Tables}

The syllabus is a guideline on how and what to teach. Therefore, teachers are required to develop an understanding of the spirit of the syllabus and to use their resourcefulness and creativity to provide the details of the syllabus in teaching. To this end teachers should begin by mastering the syllabus matrix. This concise explanation of the contents of the syllabus should enable them follow the prescribed procedure for preparing a competency-based lesson, delivering it, and designing integration activities.

\subsubsection{Assessment}

Teachers are reminded of the need to prepare and use different but appropriate assessments to be use in assessing learners from the beginning of the lesson to the end (Figure 1). These should include oral, written exercises, pair and group work, and take-home assignments. Teachers are required to encourage learners to participate in asking and answering questions during lessons. This is aimed at enabling learners achieve the exit profile by the end of the year.

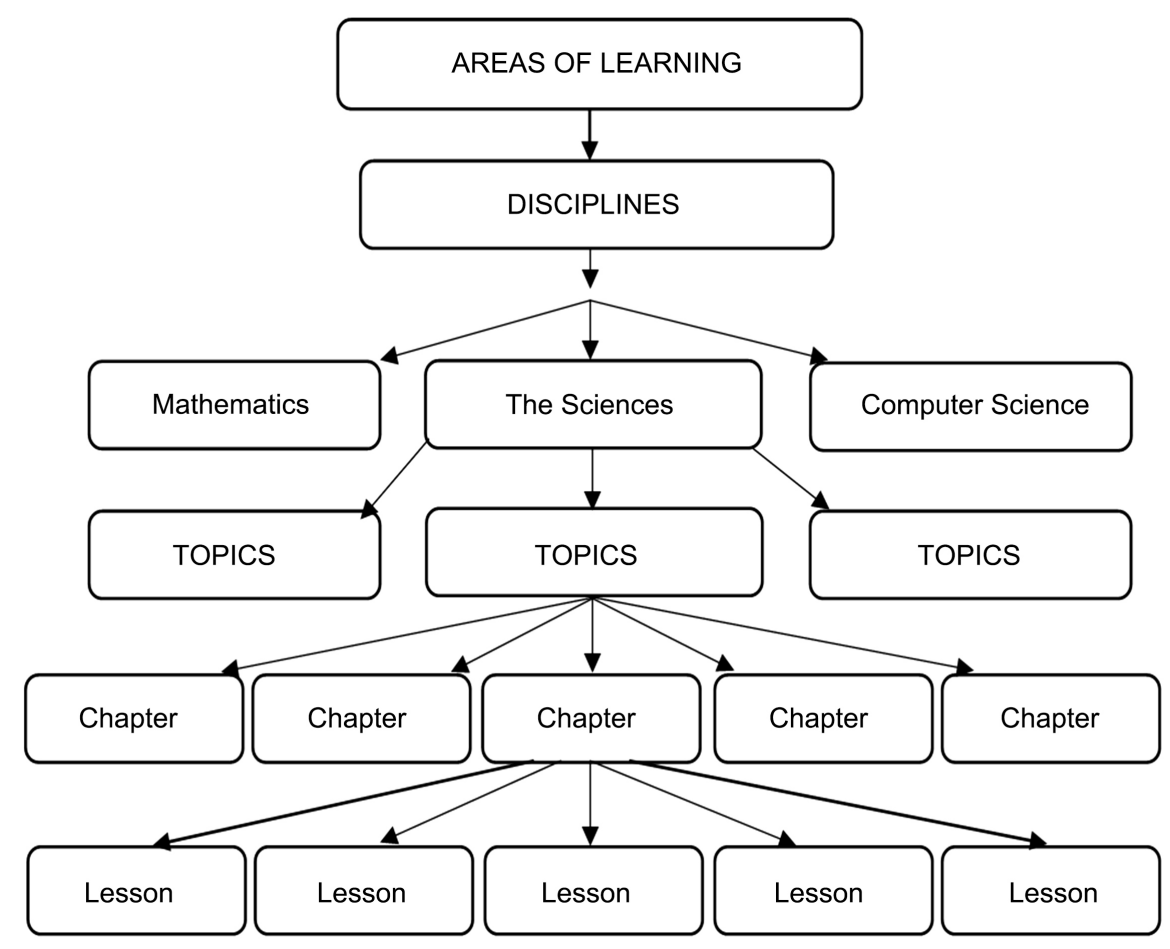

Figure 1. Graphic presentation of the organization of the syllabuses. 


\subsection{Findings}

The role of the teacher has changed from that of dispensing knowledge to that of a facilitator of learning, facilitating the appropriation of knowledge and skills by the learners for addressing their daily challenges of life.

The role of learners has evolved from that of a recipient to that of an active participant in learning. He/she is therefore, required to: put in all necessary effort, cultivate a spirit of team work, set learning goals, review her/his learning through reflection and self-assessment and collaborate in peer learning and assessment among others.

Parents are called upon to participate in the education of their children by accompanying them in their learning, making the home a comfortable and motivating learning environment and by promoting acculturation and social interaction.

The community (all educational stakeholders) is called upon to make certain contributions as an obligation towards learners, teachers, school administrators and the school infrastructure and learning spaces. This includes the provision of learning spaces that inspires learners dream big, create opportunities for feedback, rehearsal, apprenticeship, and transfer of knowledge know how and attitudes.

Each subject has core competences it has to develop in learners. These competences define and describe the essential knowledge, aptitudes and attitudes learners will acquire. These core competences are dependent on each other and in the teaching and learning interaction teachers are required to place emphasis on critical thinking, creativity, initiative, innovation and problem-solving.

In addition to core competences that should be developed from the content of the subject syllabus and the other subjects of the specific area of learning are cross-curricula competences. Their development is dependent upon learners mobilizing resources from several related subjects and learning areas. The four cross-curricula competences are; intellectual (cognition, effective and psychomotor) personal and social, methodological procedural and communicative competences.

To enhance understanding and facilitate quality teaching, the syllabi propose to teachers' a plethora of learner-centered teaching methods and strategies accompanied by detailed explanations on how to use them in preparing and facilitating instruction to deepen learning by learners.

The syllabi provide teachers the elements to be used in preparing lessons. This is followed by sample lessons which provide the structure of lesson plans and where the elements of a competency-based lesson find expression within the lesson plan format. Detailed explanations relating to how teachers should design lessons, deliver them and design the integration activities are also provided.

The nature of assessment in CBA is explained, the dimensions of teaching and the related weighting and assessment tasks provided, and how the competencies should be assessed explained accompanied by some sampled assessment instru- 
ments.

The syllabi prescribe the learner's profiles by subject at the end of each year, level and cycle.

There is a glossary of the terminologies used in the syllabi.

The syllabi are divided into 5 areas of learning (language and literature, science and technology, social sciences, personal development and arts and natural cultures), each area contains a number of corresponding disciplines. Each area of learning is officially assigned the number of interaction time per year and the weighting in relation to the other areas of learning in the curriculum.

The families of situations through which the syllabuses will be taught and learned are prescribed together with the corresponding areas of life from which they are drawn.

Teachers have been given the responsibility of identifying and using in relation to the prescribed areas of life and families of situations, additional situations relevant to their local environments.

\section{Conclusions}

The preparation of the new secondary school syllabi for Cameroon was inspired by the need to increase access, provide a $21^{\text {st }}$ century quality education which is relevant not only to the world society but equally to the Cameroon context. Drawing from international, continental and national orientations the syllabi are developed to enable learners develop and use competences, knowledge and attitudes that will facilitate their smooth insertion into the universal market place and enable them contribute to the transformation of Cameroon from an agrarian economy based on the production and sale of primary products to a manufacturing one that supplies value added goods and services. The syllabi are organized following the same principles. They are divided into five domains and each domain contains a number of related subjects. The subjects are further orginsed into modules, leading to chapters and lessons. The syllabi contain detailed information on all aspects to facilitate teaching and learning. They are essentially learner-centred with a learner-centred pedagogy. The teacher guides provide further guidance to teachers, learners, parents, and the community in terms of their roles and responsibilities to the successful implementation of the syllabi. The contents of the syllabi are highly relevant to the needs of the Cameroon society in particular and in relation to enabling learners' operate successfully in the global economy.

However, this research addresses only salient macro issues related to the syllabi. The specificities of the subject syllabus and the differences in the handling of organizational issues prompted by the nature of the subject's content, at the micro level, are not described here. The role of teacher, in preparing and delivering instruction, selecting materials, determining methods, and assessments, the organization of learners for learning-in pairs, small groups, or whole class-in relation to the demands of the subject, the competences to be developed and the 
knowledge and aptitudes learners are expected to acquire, are left for future research. Similarly, the roles of the learner, parents, and the community have not been explored in any detail.

\section{Conflicts of Interest}

The author declares no conflicts of interest regarding the publication of this paper.

\section{References}

[1] Humanium (1990) World Declaration on Education for All and Framework for Action to Meet Basic Learning Need.

[2] Dakar (2000) World Education Forum; The Dakar Framework for Action: Education for All: Meeting Our Collective Commitments.

[3] United Nations (2015) Transforming Our World: The 2030 Agenda for Sustainable Development, A/RES/70/1. https://sdgs.un.org/

[4] Tambo, I.L. (2005) National Education Policy since the 1995 Forum. Press Book Ltd., Limbe.

[5] Alemnge, F.L. (2019) Curriculum Reform in Cameroon: An Analysis of the New Primary School Curriculum. International Journal of Trend in Scientific Research and Development, 3, 902-913. https://www.ijtsrd.com/papers/ijtsrd29264.pdf

[6] Elton, G.R. (1967) The Practice of History. Fontana Library, London.

[7] Bell, J. (1993) Doing Your Research Project. Open University, Celtic Court, Buckingham.

[8] Scott, J. (1990) A Matter of Records. Polity Press, Cambridge.

[9] Luke, A., Wood, A. and Weir, K. (2012) Curriculum Design, Equity and the Technical Form of the Curriculum.

[10] Michael, J.V.W (2005) Constructing a Syllabus: A Handbook for Faculty, Teaching Assistants and Teaching Fellows. W. S. Center for Teaching and Learning. Brown University, Providence.

[11] Diamond, R.M. and Forward, I.J. (1998) The Course Syllabus: A Learning-Centered Approach. Anker Publishing Company Inc., Bolton.

[12] Halpern, D.F. and Hakel, M.D. (2003) Applying the Science of Learning to the University and Beyond: Teaching for Long-Term Retention and Transfer. Change: The Magazine of Higher Learning, 35, 36-41. https://doi.org/10.1080/00091380309604109

[13] Republique du Cameroun, Les Ministeres du Secteur de L'education (2013) Socle National des Competences.

[14] Ministry of the Economy, Planning and Regional Development (2009) Cameroon Vision 2035, Working Paper.

[15] Robertson, D.L. (1999) Professors' Perspectives on Their Teaching: A New Construct and Developmental Model. Innovative Higher Education, 23, 271-294. https://doi.org/10.1023/A:1022982907040

[16] Habanek, D.V. (2005) An Examination of the Integrity of the Syllabus. College Teaching, 53, 62-64. https://doi.org/10.3200/CTCH.53.2.62-64

[17] Grunet, J. (1997) The Course Syllabus: A Learning-Centered Approach. MA: Anker Publishing, Inc., Bolton. 
[18] Peer, K. and Martin, M. (2005) The Learner-Centered Syllabus: From Theory to Practices in Allied Health Education. Internet Journal of Allied Health Sciences and Practices, 3, No. 2.

[19] Vygotsky, L.S. (1980) Mind in Society: The Development of Higher Psychological Processes. Harvard University Press, Cambridge. https://doi.org/10.2307/j.ctvjf9vz4

[20] Brown, J.S., Collins, A. and Duguid, P. (1989) Situated Cognition and the Culture of Learning. Educational Researcher, 18, 32-42. https://doi.org/10.3102/0013189X018001032

[21] Streibel, M.J. (1989) Instructional Plans and Situated Learning: The Challenge of Schuman's Theory of Situated Action for Instructional Designers and Instructional Systems. Journal of Visual Literacy, 9, 8-34. https://doi.org/10.1080/23796529.1989.11674442

[22] Republic of Cameroon, Ministry of Secondary Education, General Inspectorate of Education (2014) Programme of Study: Literature in English (Anglophone) Secondary General Education First Cycle: Forms 3, 4 and 5. Inspectorate of Pedagogy Incharge of Letters, Arts and Languages.

[23] Republic of Cameroon, Ministry of Secondary Education, General Inspectorate of Education (2014) Biology Syllabus, Form 1 and 2: Inspectorate of Pedagogy Incharge of Science Education/Biology Department.

[24] Republic of Cameroon, Ministry of Secondary Education, General Inspectorate of Education (2014) Mathematics Teaching Syllabus, Forms 3, 4 and 5. Inspectorate of Pedagogy Incharge of Science Education/Mathematics Department. 


\section{Appendix (Abstract and Keywords in French)}

Les nouveaux programmes de l'enseignement secondaire au Cameroun: une description de l'organisation des éléments saillants.

Résumé: Cette étude propose une description des nouveaux programmes de l'enseignement secondaire entrés en vigueur au Cameroun au cours de l'année académique 2014/2015 en remplacement des programmes en vigueur au cours des trente dernières années. Les programmes actuels ont été conçus pour refléter les besoins d'apprentissage nationaux et internationaux en termes de savoirs, de savoir-faire et d'attitudes. Intégré à l'Approche de l'enseignement et de l'apprentissage basée sur les compétences, ils s'inspirent de la vision de l'éducation contenue dans les Objectifs de l'éducation pour tous (EPT), Jomtien, (1990), le Cadre d'action de Dakar (2000), l'Objectif de développement durable, 4 “Assurer une éducation inclusive et équitable de qualité et promouvoir des opportunités d'apprentissage tout au long de la vie pour tous" (p. 18, 2015), la Politique nationale d'éducation (1998), le Document de stratégie pour la croissance et l'emploi (GESP, 2010) ainsi que Cameroun Vision 2035 (2009). Structurés en cinq "domaines d'apprentissage", avec des poids différents, les programmes sont maintenus ensemble par des "familles de situations" autour desquelles des activités d'enseignement et d'apprentissage sont développées et mises en œuvre afin de permettre aux apprenants de développer à la fois les compétences disciplinaires et les compétences transversales. Les rôles spécifiques des apprenants, des enseignants, des parents et de la communauté y sont clairement définis pour en faciliter la mise en œuvre.

Mots clés: Programmes d'enseignement, approche basée sur les compétences, domaines d'apprentissage, familles de situations, modules, situations de la vie réelle, centration sur l'apprenant, compétences, compétences transversales 